\title{
An updated distribution of Solidago $\times$ niederederi (Asteraceae) in Poland
}

\author{
Artur Pliszko, Grzegorz Łazarski, Paweł Kalinowski, \\ Wojciech Adamowski, Lucjan Rutkowski \& Radosław Puchałka
}

An updated distribution of Solidago $\times$ niederederi (Asteraceae) in Poland. - Acta Mus. Siles. Sci. Natur., 66: 253-258, 2017.

\begin{abstract}
In this paper, an updated map of the distribution of Solidago $\times$ niederederi, a natural hybrid between $S$. canadensis and S. virgaurea, in Poland is presented using the ATPOL cartogram method. A compiled list of 55 localities of the hybrid within 40 cartogram units (10-km squares) is provided and its negative impact on $S$. virgaurea is highlighted.
\end{abstract}

Key words : alien species, biological recording, Central Europe, geographical range, hybrid.

\section{Introduction}

Solidago $\times$ niederederi Khek (Asteraceae), a natural hybrid between North American S. canadensis L. s. 1. and European S. virgaurea L. s. str., was described from Austria at the beginning of the $20^{\text {th }}$ century (Khek 1905, Pliszko 2015a, Pliszko \& Zalewska-Gałosz 2016). Nowadays, it is known from a dozen countries in Europe, including Austria, Italy, the United Kingdom, Denmark, Sweden, Norway, Germany, Poland, Lithuania, Latvia, and Russia (Nilsson 1976, Burton 1980, Sunding 1989, Mayorov et al. 2012, Pliszko 2013, Stace et al. 2015, Gudžinskas \& Petrulaitis 2016, Karpavičienė \& Radušienè 2016, Pagitz 2016, Pliszko \& Zalewska-Gałosz 2016). As a hybrid between alien and native species, it should be treated as alien taxon in Europe, according to Pyšek et al. (2004). Solidago $\times$ niederederi is a perennial plant morphologically more or less intermediate between its parental species (Nilsson 1976, Pliszko 2013, Gudžinskas \& Žalneravičius 2016, Karpavičienè \& Radušienè 2016). It forms characteristic clonal clusters of shoots (generative and vegetative ramets) similar to those found in S. canadensis and S. virgau-rea. However, there is no evidence that the hybrid (at least the $\mathrm{F}_{1}$ generation) produces long rhizomes typical of S. canadensis (Pliszko \& Kostrakiewicz-Gierałt 2017). Nevertheless, the hybrid is able to produce numerous generative ramets and viable seedlings ( $F_{2}$ generation) as a part of its naturalization strategy (Pliszko \& Kostrakiewicz-Gierałt 2017). In this respect, it should be pointed out that $S$. ×niederederi spreads by wind-dispersed achenes, however, the seed-set in the hybrid is limited by its reduced pollen viability (Migdałek et al. 2014, Karpavičienè \& Radušienè 2016). Solidago $\times$ niederederi usually occurs in disturbed areas where $S$. canadensis and $S$. virgaurea share the habitats. It is found on abandoned fields, roadside verges and slopes, railway embankments, in disused quarries and tree plantations, often close to both parental species (Nilsson 1976, Pliszko 2013, Stace et al. 2015, Gudžinskas \& Petrulaitis 2016, Pliszko \& Zając 2016, Pliszko \& Kostrakiewicz-Gierałt 2017).

The first record of $S$. ×niederederi in Poland was provided by Rostański (1971) who identified it among the herbarium materials (one specimen) collected by Ambrożewska in Drohiczyn, Podlaskie Province, in 1957. This specimen is deposited at the Herbarium of the Faculty of Biology of the University of Warsaw (WA0000035527!). Up to 2016, more than 40 localities of the hybrid have been registered in the north-eastern, central, western, and southern parts of the country (Pliszko 2013, 2015b, Pliszko \& Zając 2016, Jaźwa et al. 2018, Pliszko \& Kostrakiewicz-Gierałt 2017). However, not all of them were presented in reference to the ATPOL cartogram grid (Zając 1978). The aim of this study is to update the distribution of $S$. ×niederederi in Poland, with new unpublished records, using the ATPOL cartogram method. 


\section{Material and methods}

New records of Solidago $\times$ niederederi were obtained during field surveys conducted in 2014-2017. Published data on the occurrence of the hybrid in Poland were also included (Rostański 1971, Pliszko 2013, 2015b, Pliszko \& Zając 2016, and Jaźwa et al. 2018). Identification of $S$. ×niederederi followed morphological features given by Nilsson (1976) and Gudžinskas \& Žalneravičius (2016). Distribution map was prepared based on the ATPOL cartogram method (Zając 1978), involving 10-km square as a basic cartogram unit. Localities were revised using the Online ATPOL grid (Komsta 2016, www.komsta.net/atpol). Voucher specimens of $S$. $\times$ niederederi are deposited in the Herbarium of the Institute of Botany of the Jagiellonian University in Kraków (KRA), the Herbarium of the Department of Biology and Environment Protection of the Nicolaus Copernicus University in Torun (TRN), and the Herbarium of the Białowieża Geobotanical Station of the University of Warsaw (BSG), as well as in one private herbarium collection.

\section{Results}

In this study, distribution of Solidago xniederederi in Poland is updated with 10 new localities which are situated within seven new cartogram units (10-km squares) and three known cartogram units (10-km squares) of the ATPOL grid. Currently, the hybrid is known from 55 localities situated within 40 cartogram units (10-km squares) of the ATPOL grid (Fig. 1). Moreover, it occurs mostly on abandoned fields (Fig. 2) and its known localities are concentrated in the north-eastern and southern parts of the country (Fig. 1). Solidago $\times$ niederederi is a new taxon in the flora of the Torun Basin and Bielsk Plain.

Explanations: The list concerns new and known records of the hybrid in Poland and is arranged by the ATPOL cartogram codes (capital letters indicate 100-km squares, numbers indicate $10-\mathrm{km}$ squares). The cartogram units (10-km squares) in which the hybrid has been recorded for the first time are indicated with bold. The list includes the name of the locality, type of habitat, date of collection, name of collector, and an acronym of the herbarium in which the voucher specimens are deposited. Localities situated within the same cartogram unit are separated by a semicolon.

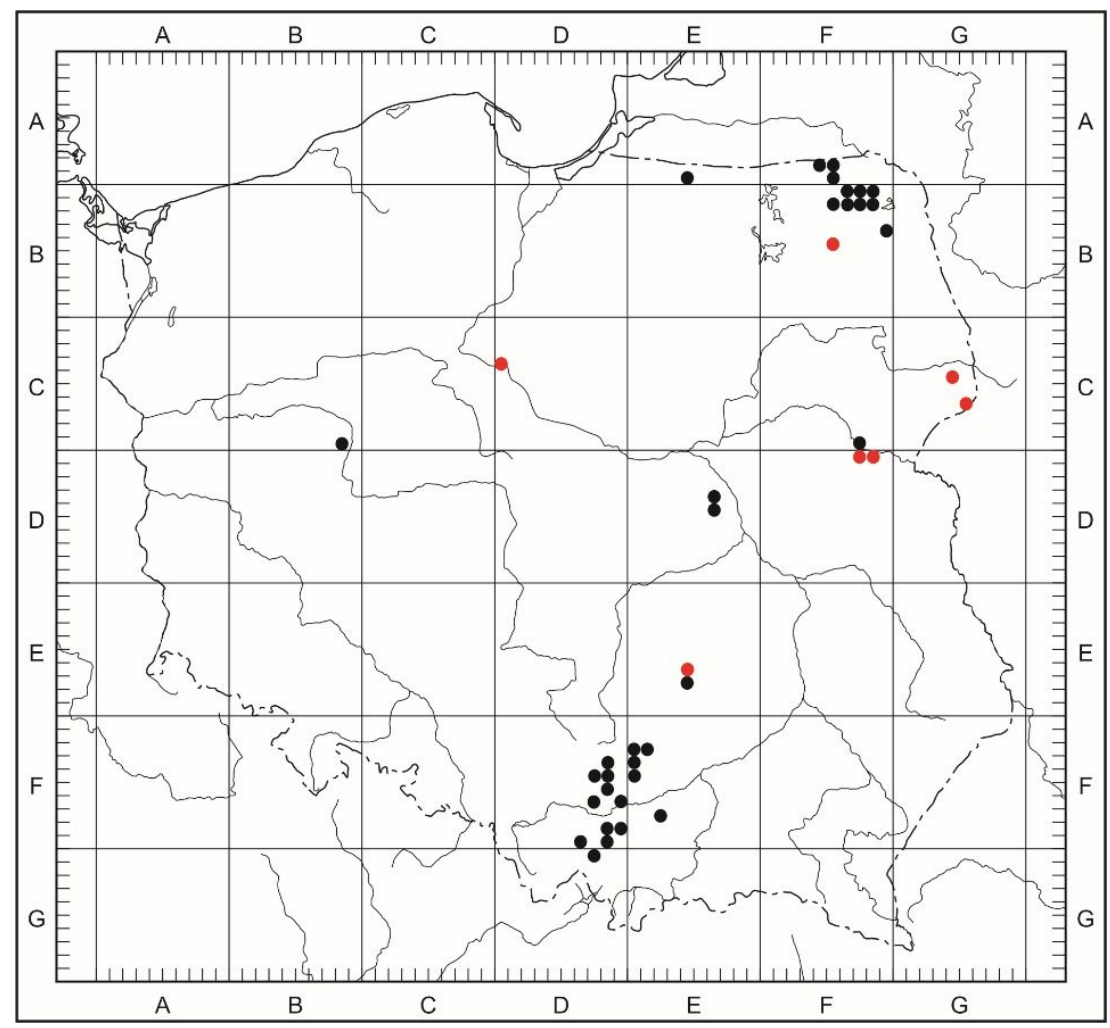

Fig 1: An updated distribution map of Solidago $\times$ niederederi in Poland using the ATPOL cartogram grid (red dots indicate cartogram units in which the hybrid has been recorded for the first time, black dots indicate cartogram units in which the hybrid has been previously recorded). 


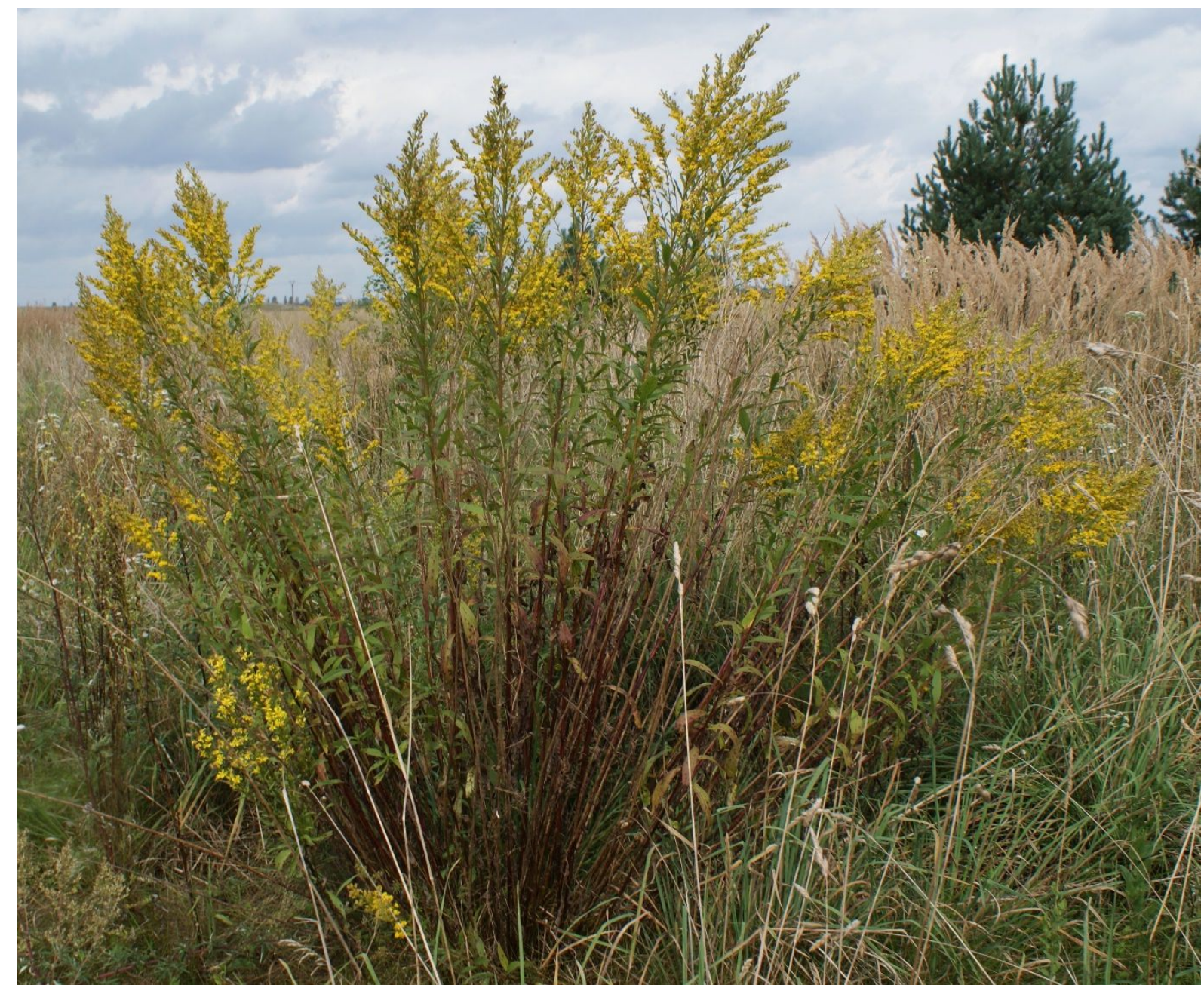

Fig 2: Solidago $\times$ niederederi on an abandoned field near Suwałki, NE Poland (photo by A. Pliszko, 18 Aug 2014).

\section{List of new records:}

DC30 - Toruń Czerniewice, disused gravel pit in pine forest, 29 Sep 2017, leg. L. Rutkowski, TRN.

DF58 - between Zelków and Wierzchowie, abandoned fields, 8 Sep 2017, leg. A. Pliszko, KRA.

DF98 - Sułkowice, abandoned fields, 7 Oct 2017, leg. A. Pliszko, KRA.

EE64 - Kostomłoty Pierwsze, edge of abandoned fields near scrubs, 25 Sep 2014, leg. G. Łazarski, KRA.

FB08 - Suwałki near Okuniowiec, abandoned fields, 29 Jul 2017, leg. A. Pliszko, KRA.

FB45 - Ełk, ruderal ground near railway track, 27 Jul 2017, leg. A. Pliszko, KRA.

FD07 - Rudniki near Repki, abandoned field, 11 Sep 2016, leg. P. Kalinowski, private collection (locality destroyed in 2017 by the resumption of agricultural land use).

FD08 - Ruska Strona near Korczew, long-abandoned meadow, 23 Aug 2016, 1 Sep 2017, leg. P. Kalinowski, private collection.

GC44 - Skupowo, abandoned field, 31 Aug 2017, leg. W. Adamowski, BSG.

GC65 - Białowieża Clearing, abandoned fields, 8 Sep 2016, 13 Sep 2016, leg. W. Adamowski, BSG.

\section{List of known records:}

BC98 - Poznań near Nad Różanym Potokiem Street, abandoned field, 10 Sep 2015, leg. A. Pliszko, KRA; Poznań near Umultowska Street, ruderal ground, 10 Sep 2015, leg. A. Pliszko, KRA.

DF38 - near Wolbrom, abandoned field, 13 Sep 2015, leg. A. Pliszko, KRA; Podchybie, abandoned field, 9 Sep 2016,

leg. A. Pliszko, KRA.

DF47 - Kogutek, tree plantation, 30 Aug 2014, leg. A. Pliszko, KRA.

DF48 - Zadroże, abandoned field, 26 Aug 2015, leg. A. Pliszko, KRA.

DF58 - Czajowice, abandoned field, 29 Aug 2014, leg. A. Pliszko, KRA. 
DF67 - Wrzosy, abandoned field, 15 Sep 2013, leg. A. Pliszko, KRA; Rudno, abandoned field, 11 Sep 2016, leg. A. Pliszko, KRA.

DF69 - Kraków, disused limestone quarry, 24 Aug 2013, leg. A. Pliszko, KRA.

DF88 - Izdebnik, abandoned field, 29 Aug 2013, leg. A. Pliszko, KRA; Lanckorona near Izdebnik, abandoned field, 22 Aug 2015, leg. A. Pliszko, KRA.

DF89 - Głogoczów, abandoned field, 7 Sep 2013, leg. A. Pliszko, KRA.

DF96 - Tarnawska Góra near Śleszowice, abandoned field, 3 Oct 2013, leg. A. Pliszko, KRA.

DF98 - near Jasienice and Harbutowice, abandoned field, 3 Oct 2013, leg. A. Pliszko, KRA; Harbutowice near Sułkowice, abandoned field, 30 Sep 2015, leg. A. Pliszko, KRA; Palcza, abandoned fields, 1 Oct 2016, leg. A. Pliszko, KRA.

DG07 - Budzów near Jachówka, abandoned field, 30 Sep 2014, leg. A. Pliszko, KRA.

EA94 - Wysieka, abandoned field near pine forest, 17 Aug 2013, leg. A. Pliszko, KRA.

ED36 - Warszawa Jeziorki, abandoned field, 16 Sep 2014, leg. A. Pliszko, KRA.

ED46 - Zalesie Górne near Łbiska, abandoned fields, 17 Sep 2014, leg. A. Pliszko, KRA.

EE74 - Kielce, abandoned field, 5 Sep 2015, leg. A. Pliszko, KRA.

EF20 - Podleśna Wola, roadside slope, 24 Sep 2016, leg. A. Pliszko, KRA; near Podleśna Wola, abandoned field, 24 Sep 2016, leg. A. Pliszko, KRA.

EF21 - near Książ Wielki and Podbrzezie, tree plantation, 12 Sep 2015, leg. A. Pliszko, KRA.

EF30 - Miechów, balk between abandoned field and arable field, 21 Sep 2014, leg. A. Pliszko, KRA.

EF40 - near Januszowice and Lipna Wola, abandoned fields, 19 Sep 2014, leg. A. Pliszko, KRA.

EF72 - Łapczyca, abandoned field, 13 Sep 2014, leg. A. Pliszko, KRA.

FA84 - Gołdap, abandoned field, 6 Aug 2015, leg. A. Pliszko, KRA.

FA85 - Ostrowo near Pluszkiejmy, roadside slope and arable field with a grass-legume mixture, 7 Sep 2014, leg. A. Pliszko, KRA; near Kociołki, abandoned fields, 7 Sep 2014, leg. A. Pliszko, KRA.

FA95 - Górne, abandoned field, 27 Aug 2016, leg. A. Pliszko, KRA.

FB06 - Mieruniszki, edge of tree plantation, 17 Aug 2011, leg. A. Pliszko, KRA; Bakałarzewo, abandoned field near allotments, 19 Aug 2014, leg. A. Pliszko, KRA; Las Garbaski, forest clearing, 24 Aug 2016, leg. A. Pliszko, KRA.

FB07 - Taciewo, abandoned field, 21 Aug 2014, leg. A. Pliszko, KRA.

FB08 - Suwałki near Czarnoziem, abandoned fields, 2 Sep 2014, leg. A. Pliszko, KRA; Suwałki near Kuków and Bród Mały, abandoned fields, 17 Aug 2015, leg. A. Pliszko, KRA.

FB15 - Pieńki near Możne, roadside ditch, 25 Aug 2016, leg. A. Pliszko, KRA.

FB16 - near Dąbrowskie Osada, roadside ditch, 1 Aug 2015, leg. A. Pliszko, KRA; Możne near Olecko, abandoned fields and tree plantation, 13 Aug 2015, leg. A. Pliszko, KRA.

FB17 - Kotowina near Karasiewo, abandoned field, 19 Aug 2014, leg. A. Pliszko, KRA.

FB18 - Suwałki, abandoned field, 18 Aug 2014, leg. A. Pliszko, KRA.

FB39 - Augustów, railway embankment near the edge of pine forest, 18 Aug 2015, leg. A. Pliszko, KRA.

FC97 - Drohiczyn, dry, sunny slope, 20 Aug 1957, leg. M. Ambrożewska, WA.

\section{Discussion}

Distribution of natural hybrids between alien and native vascular plant species is poorly recognized in Poland (Pliszko 2015b). Unfortunately, the hybrids are easily overlooked during field surveys due to close resemblance to their parental species (Preston \& Pearman 2015). Nevertheless, biological recording of hybrids between alien and native species is useful for classification of alien species (Blackburn et al. 2014). Solidago $\times$ niederederi is one of the bestdocumented hybrids between alien and native plant species occurring in Poland (Pliszko 2015b, Pliszko \& Zalewska-Gałosz 2016, Pliszko \& Kostrakiewicz-Gierałt 2017). It should be pointed out that the occurrence of $S$. ×niederederi reflects the ongoing invasion of $S$. canadensis. It is clearly noticeable in the north-eastern part of the country, especially on the outskirts of small towns such as Suwałki and Gołdap, where $S$. canadensis exponentially colonized numerous abandoned fields and ruderal ground during the last 10 years.

The first stand of $S$. ×niederederi in Torun, north-central Poland, was discovered in 2012

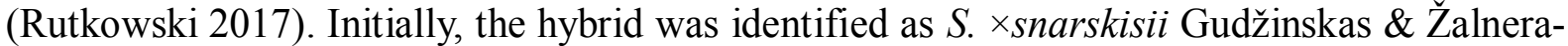
vičius, a hybrid between $S$. gigantea Aiton and S. virgaurea (Gudžinskas \& Žalneravičius 2016 ), due to the co-occurrence of $S$. gigantea and $S$. virgaurea and absence of $S$. canadensis at the site occupied. Nevertheless, a critical revision on herbarium specimens of the hybrid from the above-mentioned locality revealed the identity of $S$. $\times$ niederederi. It is commonly known that plant hybrids usually occur together with their parental species (Preston \& Pearman 2015, 
Stace et al. 2015). However, there are a few localities in Poland where $S$. ×niederederi was found without or only with one of its parental species. On the other hand, the presence of $S$.

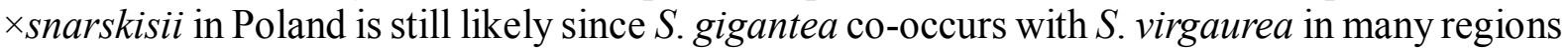
of the country (Zając \& Zając 2001).

Considering the predicted distribution of $S$. ×niederederi in Poland (Pliszko \& Zając 2016, Jaźwa et al. 2018) and newly presented records we surmised that the hybrid is commonly distributed throughout the country wherever its parental species occur in close proximity to each other. Similar assumptions were made on hybrid distribution in Austria (Pagitz 2016) and Lithuania (Gudžinskas \& Žalneravičius 2016, Karpavičienė \& Radušienè 2016). However, further studies on hybrid occurrence in Poland are needed. In this respect, we recommend investigating abandoned fields and other habitats abundantly occupied by S. canadensis and $S$. virgaurea. It is also worth mentioning that as an established alien spreading by winddispersed achenes (Pliszko \& Kostrakiewicz-Gierałt 2017), S. ×niederederi may become an invasive species in the future. According to Pagitz (2016), due to its self-incompatibility, the hybrid can pose a threat to native $S$. virgaurea by introgressive hybridization. Moreover, it seems to be a strong competitor for insect pollinators (Pagitz 2016). In conclusion, we hope that botanists and ecologists will pay a lot more attention to the occurrence and negative impacts of $S$. $\times$ niederederi.

Acknowledgements: The first author would like to thank Maja Graniszewska, Ph. D., curator of the Herbarium of the Faculty of Biology of the University of Warsaw, for the loan of herbarium sheet of Solidago xniederederi collected by Ambrożewska. The study was financially supported by the Institute of Botany of the Jagiellonian University in Kraków (K/ZDS/006305).

\section{References}

Blackburn T.M., Essl F., Evans T., Hulme P.E., Jeschke J.M., Kühn I., Kumschick S., Marková Z., Mrugała A., Nentwig W., Pergl J., Pyšek P., Rabitsch W., Ricciardi A., Richardson D.M., Sendek A., Vilà M., Wils on J.R.U., Winter M., Genovesi P., Bacher S. (2014): A unified classification of alien species based on the magnitude of their environmental impacts. - PLoS Biol. 12(5): e1001850.

Burton R. (1980): Solidago ×niederederi Khek in Britain. - Watsonia 13: 123-124.

Gudžinskas Z. \& Petrulaitis L. (2016): New alien plant species recorded in the southern regions of Latvia. Bot. Lith. 22: 153-160.

Gudžinskas Z. \& Žalneravičius E. (2016): Solidago $\times$ snarskisii nothosp. nov. (Asteraceae) from Lithuania and its position in the infrageneric classification of the genus. - Phytotaxa 253: 147-155.

Jaźwa M., Jędrzejczak E., Klichowska E. \& Pliszko A. (2018): Predicting the potential distribution area of Solidago $\times$ niederederi (Asteraceae). - Turk. J. Bot. 42(1): 51-56.

Karpavičienè B. \& Radušienè J. (2016): Morphological and anatomical characterization of Solidago $\times$ niederederi and other sympatric Solidago species. - Weed Sci. 64: 61-70.

Khek E. (1905): Floristisches aus Ober-Oesterreich. - Allg. Bot. Z. Syst. 11: 22-23.

Komsta Ł. (2016): Rewizja matematyczna siatki geobotanicznej ATPOL - propozycja algorytmów konwersji współrzędnych. - Annales UMCS, Sectio E Agricultura 71(1): 31-37.

Mayorov S.R., Bochkin V.D., Nasimovich Yu.A. \& Shcherbakov A.V. (2012): Adventivnaya flora Moskvy i Moskovskoi oblastii. Moscow, Russia: KMK.

Migdałek G., Kolczyk J., Pliszko A., Kościńska-Pająk M. \& Słomka A. (2014): Reduced pollen viability and achene development in Solidago $\times$ niederederi Khek from Poland. - Acta Soc. Bot. Pol. 83(3): 251-255.

Nilsson A. (1976): Spontana gullrishybrider (Solidago canadensis $\times$ virgaurea) i Sverige och Danmark. Sven. Bot. Tidskr. 70: 7-16.

Pagitz K. (2016): Solidago $\times$ niederederi $(S$. canadensis $\times$ S. virgaurea ssp. virgaurea $)$ in the Eastern Alps. pp. 194. In: Ries C. \& Krippel Y. (eds): Biological invasions: interactions with environmental change. Book of abstracts. NEOBIOTA 2016 - $9^{\text {th }}$ International Conference on Biological Invasions. Vianden, Luxembourg 1416 September 2016, Fondation faune-flore, Vianden, Luxembourg, 255 pp.

Pliszko A. (2013): A new locality of Solidago $\times$ niederederi Khek (Asteraceae) in Poland. - Biodiv. Res. Conserv. 29: 57-62.

- (2015a): Neotypification of Solidago ×niederederi (Asteraceae). - Phytotaxa 230(3): 297-298. 
- (2015b): Zdolność do hybrydyzacji z rodzimymi gatunkami roślin jako przejaw inwazyjności obcych gatunków we florze Polski. pp. 93-102. In: Krzysztofiak L. \& Krzysztofiak A. (eds): Inwazyjne gatunki obcego pochodzenia zagrożeniem dla rodzimej przyrody. Stowarzyszenie „Człowiek i Przyroda”, Krzywe, 240 pp.

Pliszko A. \& Kostrakiewicz-Gierałt K. (2017): Resolving the naturalization strategy of Solidago $\times$ niederederi (Asteraceae) by the production of sexual ramets and seedlings. - Plant Ecol. 218: 1243-1253.

Pliszko A. \& Zając M. (2016): Current and potential distribution of Solidago $\times$ niederederi (Asteraceae) in Poland. pp. 163. In: Ries C. \& Krippel Y. (eds): Biological invasions: interactions with environmental change. Book of abstracts. NEOBIOTA $2016-9^{\text {th }}$ International Conference on Biological Invasions. Vianden, Luxembourg, 14-16 September 2016, Fondation faune-flore, Vianden, Luxembourg, 255 pp.

Pliszko A. \& Zalewska-Gałosz J. (2016): Molecular evidence for hybridization between invasive Solidago canadensis and native $S$. virgaurea. - Biol. Invasions 18: 3103-3108.

Preston C.D. \& Pearman D.A. (2015): Plant hybrids in the wild: evidence from biological recording. - Biol. J. Linn. Soc. 115: 555-572.

Pyšek P., Richardson D.M., Rejmánek M., Webster G.L., Williamson M. \& Kirschner J. (2004): Alien plants in checklists and floras: towards better communication between taxonomists and ecologists. - Taxon 53(1): 131-143.

Rostański K. (1971): Solidago L. pp. 116-121. In: Pawłowski B. \& Jasiewicz A. (eds): Flora Polska. Rośliny naczyniowe Polski i ziem ościennych, vol. 12, Państwowe Wydawnictwo Naukowe, Warszawa, Kraków, 416 pp.

Rutkowski L. (2017): Piękna i zagrożona jest nasza flora ojczysta cz. 5. - Eko Przyjaciel 01/17(11): 8-10.

Stace C. A., Preston C. D. \& Pearman D. A. (2015): Hybrid flora of the British Isles. Botanical Society of Britain and Ireland, Bristol, UK, $501 \mathrm{pp.}$

Sunding P. (1989): Naturaliserte Solidago-(gullris-) arter i Norge. - Blyttia 47: 23-27.

Zając A. (1978): Atlas of distribution of vascular plants in Poland (ATPOL). - Taxon 27(5-6): 481-484.

Zając A. \& Zając M. (eds) (2001): Atlas rozmieszczenia roślin naczyniowych w Polsce. Nakładem Instytutu Botaniki Uniwersytetu Jagiellońskiego, Kraków, 714 pp.

Authors' addresses: Artur Pliszko \& Grzegorz Łazarski, Department of Taxonomy, Phytogeography and Paleobotany, Institute of Botany, Jagiellonian University in Kraków, Kopernika 31, 31-501 Kraków, Poland.

E-mail: artur.pliszko@uj.edu.pl (corresponding author), grzegorz.lazarski@gmail.com

Paweł Kalinowski, Institute of Technology and Life Sciences, Al. Hrabska 3, 05-090 Falenty, Poland; e-mail: kumat@hotmail.com

Wojciech Adamowski, Białowieża Geobotanical Station, Faculty of Biology, University of Warsaw, Sportowa 19, 17-230 Białowieża, Poland; e-mail: w.adamowski@uw.edu.pl

Lucjan Rutkowski, Chair of Geobotany and Landscape Planning, Nicolaus Copernicus University in Toruń, Lwowska 1, 87-100 Toruń, Poland; e-mail: lrutkow@umk.pl

Radosław Puchałka, Chair of Ecology and Biogeography, Nicolaus Copernicus University in Toruń, Lwowska 1,87-100 Toruń, Poland; e-mail: puchalka@umk.pl 